medRxiv preprint doi: https://doi.org/10.1101/2021.06.18.21258578; this version posted June 21, 2021. The copyright holder for this preprint

(which was not certified by peer review) is the author/funder, who has granted medRxiv a license to display the preprint in perpetuity.

It is made available under a CC-BY-NC-ND 4.0 International license .

\title{
Monogenic and Polygenic Contributions to QTc Prolongation in the Population
}

\section{Brief Title: Monogenic and Polygenic Contributions to the QTc}

Victor Nauffal MD ${ }^{\mathrm{a}, \mathrm{b}, *}$, Valerie N Morrill MS ${ }^{\mathrm{b}, *}$, Sean J Jurgens BSc ${ }^{\mathrm{b}}$, Seung Hoan Choi PhD ${ }^{\mathrm{b}}$, Amelia W Hall PhD ${ }^{\mathrm{b}}$, Lu-Chen Weng $\mathrm{PhD}^{\mathrm{b}}$, Jennifer L Halford $\mathrm{MD}^{\mathrm{b}}$, Christina Austin-Tse $\mathrm{PhD}^{\mathrm{c}}$, Christopher M Haggerty $\mathrm{PhD}^{\mathrm{d}}$, Stephanie L Harris MSc, ${ }^{\mathrm{e}}$ Eugene Wong MSc, ${ }^{\mathrm{e}}$ Alvaro Alonso MD, $\mathrm{PhD}^{\mathrm{f}}$, Dan E Arking $\mathrm{PhD}^{\mathrm{g}}$, Emelia J Benjamin MD, ScM ${ }^{\mathrm{h}}$, Eric Boerwinkle $\mathrm{PhD}^{\mathrm{i}}$, Yuan-I Min $\mathrm{PhD}^{\mathrm{j}}$, Adolfo Correa MD, PhDi, Brandon K Fornwalt MD, PhD ${ }^{\mathrm{d}}$, Susan R Heckbert $\mathrm{MD}, \mathrm{PhD}^{\mathrm{k}}$, NHLBI Trans-Omics for Precision Medicine (TOPMed) Consortium, Charles Kooperberg $\mathrm{PhD}^{1}$, Henry J Lin $\mathrm{MD}^{\mathrm{m}}$, Ruth JF Loos $\mathrm{PhD}^{\mathrm{n}}$, Kenneth M Rice PhD ${ }^{\mathrm{o}}$, Namrata Gupta PhD, PMPp, Thomas W Blackwell PhD ${ }^{\mathrm{q}}$, Braxton D Mitchell PhD, $\mathrm{MPH}^{\mathrm{r}}$, Alanna C Morrison $\mathrm{PhD}^{\mathrm{i}}$, Bruce M Psaty MD, $\mathrm{PhD}^{\mathrm{s}}$, Wendy S Post MD, MSt, Susan Redline MD, MPH Heidi L Rehm PhD ${ }^{\mathrm{c}, \mathrm{p}}$, Stephen S Rich PhD ${ }^{\mathrm{v}}$, Jerome I Rotter $\mathrm{MD}^{\mathrm{m}}$, Elsayed Z Soliman MD, $\mathrm{MSc}^{\mathrm{w}}$, Nona Sotoodehnia MD, MPH${ }^{\mathrm{k}}$, Kathryn L Lunetta $\mathrm{PhD}^{\mathrm{h}}$, Patrick T Ellinor MD, $\mathrm{PhD}^{\mathrm{b}, \mathrm{x}, \dagger}$, Steven A Lubitz MD, MPH ${ }^{\mathrm{b}, \mathrm{x}, \dagger}$

* Authors contributed equally to this manuscript

†ointly supervised the work
a. Division of Cardiovascular Medicine, Brigham and Women's Hospital, Boston, MA.
b. Cardiovascular Disease Initiative, Broad Institute, Cambridge, MA.
c. Center for Genomic Medicine, Massachusetts General Hospital, Boston, MA.
d. Department of Translational Data Science and Informatics, Geisinger, Danville, PA.
e. Cardiovascular Genetics Program, Massachusetts General Hospital, Boston, MA.
f. Department of Epidemiology, Rollins School of Public Health, Emory University, Atlanta, GA, USA.
g. Center for Complex Disease Genomics, McKusick-Nathans Institute of Genetic Medicine, Johns Hopkins University School of Medicine, Baltimore, MD, USA.
h. Boston University School of Public Health, Boston, MA.
i. Health Science Center at Houston, University of Texas, Houston, TX.
j. Department of Medicine, University of Mississippi Medical Center, Jackson, MS.
k. Cardiovascular Health Research Unit and Department of Medicine, University of Washington, Seattle, WA.
1. Division of Public Health Sciences, Fred Hutchinson Cancer Research Center, Seattle, WA.
m. The Institute for Translational Genomics and Population Sciences, Department of Pediatrics, The Lundquist Institute for Biomedical Innovation at Harbor-UCLA Medical Center, Torrance, CA.
n. The Charles Bronfman Institute for Personalized Medicine, Icahn School of Medicine at Mount Sinai, NY.
o. Department of Biostatistics, University of Washington, Seattle, Washington, USA.


medRxiv preprint doi: https://doi.org/10.1101/2021.06.18.21258578; this version posted June 21, 2021. The copyright holder for this preprint (which was not certified by peer review) is the author/funder, who has granted medRxiv a license to display the preprint in perpetuity. It is made available under a CC-BY-NC-ND 4.0 International license .

p. Program in Medical and Population Genetics, Broad Institute of MIT and Harvard, Cambridge, 02142, Massachusetts, USA.

q. Department of Biostatistics and Center for Statistical Genetics, University of Michigan, Ann Arbor, Michigan, USA.

r. Division of Endocrinology, Diabetes and Nutrition, University of Maryland School of Medicine, Baltimore, MD.

s. Cardiovascular Health Research Unit, Departments of Medicine, Epidemiology and Health Services, University of Washington, Seattle, WA.

t. Division of Cardiology, Department of Medicine, Johns Hopkins University School of Medicine, Baltimore, MD.

u. Harvard Medical School, Brigham and Women's Hospital, Boston, MA.

v. Center for Public Health Genomics and Department of Public Health Sciences, University of Virginia, Charlottesville, VA.

w. Epidemiological Cardiology Research Center (EPICARE), Wake Forest School of Medicine, Winston Salem, NC.

x. Cardiac Arrhythmia Service and Cardiovascular Research Center, Massachusetts General Hospital, Boston, MA.

\section{Funding}

This work was supported by National Institutes of Heatlh (NIH) grant 1R01HL139731 and American Heart Association (AHA) 18SFRN34250007 to Dr. Lubitz. Dr. Ellinor is funded by the Fondation Leducq (14CVD01), the NIH (1RO1HL092577,R01HL128914,K24HL105780), and by a grant from the AHA Strategically Focused Research Networks (18SFRN34110082). Dr. Sotoodehnia is funded by the NIH (R01HL141989). Dr. Nauffal is funded by a training grant from the NIH (T32HL007604). Dr. Loos is funded by the NIH (R01DK110113; R01DK075787; R01DK107786; R01HL142302; R01HG010297; R01DK124097; R01HL151152). Dr. Benjamin is funded by the NIH (R01HL092577) and AHA (AF AHA_18SFRN34110082). Molecular data for the Trans-Omics in Precision Medicine (TOPMed) program was supported by the National Heart, Lung and Blood Institute (NHLBI). Core support including centralized genomic read mapping and genotype calling, along with variant quality metrics and filtering were provided by the TOPMed Informatics Research Center (3R01HL-117626-02S1; contract HHSN268201800002I). Core support including phenotype harmonization, data management, sample-identity QC, and general program coordination were provided by the TOPMed Data Coordinating Center (R01HL-120393; U01HL-120393; contract HHSN268201800001I).

\section{Disclosures}

Dr. Psaty serves on the Steering Committee of the Yale Open Data Access Project funded by Johnson \& Johnson. Drs. Haggerty and Fornwalt receive sponsored research support from Tempus Labs. Dr. Lubitz receives sponsored research support from Bristol Myers Squibb / Pfizer, Bayer AG, Boehringer Ingelheim, Fitbit, and IBM, and has consulted for Bristol Myers Squibb / Pfizer, Bayer AG, and Blackstone Life Sciences. Dr. Ellinor receives sponsored research support from Bayer AG, Novartis, Myokardia and Quest. Remaining authors have nothing to disclose. 
medRxiv preprint doi: https://doi.org/10.1101/2021.06.18.21258578; this version posted June 21, 2021. The copyright holder for this preprint (which was not certified by peer review) is the author/funder, who has granted medRxiv a license to display the preprint in perpetuity.

\section{It is made available under a CC-BY-NC-ND 4.0 International license .}

\section{Acknowledgements}

We gratefully acknowledge the studies and participants who provided biological samples and data for TOPMed and the study participants of the United Kingdom Biobank.

\section{Disclaimer}

The views expressed in this manuscript are those of the authors and do not necessarily represent the views of the National Heart, Lung, and Blood Institute; the National Institutes of Health; or the U.S. Department of Health and Human Services.

\section{Corresponding Author:}

Steven A. Lubitz, MD, MPH

Cardiac Arrhythmia Service

Massachusetts General Hospital

55 Fruit Street

Boston, MA 02114

Email: slubitz@mgh.harvard.edu

Telephone: 617-726-5036

Fax: 617-726-5806 
medRxiv preprint doi: https://doi.org/10.1101/2021.06.18.21258578; this version posted June 21, 2021. The copyright holder for this preprint (which was not certified by peer review) is the author/funder, who has granted medRxiv a license to display the preprint in perpetuity.

It is made available under a CC-BY-NC-ND 4.0 International license .

\begin{abstract}
Background: Rare sequence variation in genes underlying the long QT syndrome (LQTS) and common polygenic variation influence QT interval duration. It is unclear how rare and common variation contribute to QT interval duration in the general population.
\end{abstract}

Objectives: Investigate monogenic and polygenic contributions to QT interval duration and the role of polygenic variation in modulating phenotypic expression of rare monogenic variation.

Methods: We performed a genome wide association study (GWAS) of QTc duration in 44,979 United Kingdom Biobank (UKBB) participants and created a polygenic risk score (PRS). The PRS was validated in 39,800 independent UKBB participants. Among 26,976 participants with whole genome sequencing and ECG data in the TransOmics for Precision Medicine (TOPMed) program, we identified 160 carriers of putative pathogenic rare variants in 10 LQTS genes. We examined QTc associations with the PRS and with LQTS rare variants in TOPMed.

Results: Twenty independent loci (4 novel) were identified by GWAS. The PRS comprising 565 common variants was significantly associated with QTc duration in TOPMed $\left(\mathrm{p}=1.1 \times 10^{-64}\right)$. Carriers of LQTS rare variants had longer QTc intervals than non-carriers $(\triangle \mathrm{QTc}=10.9 \mathrm{~ms}[7.4-$ 14.4] for all LQTS genes; $\triangle \mathrm{QTc}=26.5 \mathrm{~ms}$ [20.7-32.3] for $K C N Q 1, K C N H 2$ and $S C N 5 A$ ). $16.7 \%$ of individuals with QTc>480 ms carried either a rare variant in a LQTS gene or had a PRS in the top decile (3.4\% monogenic, 13.6\% top decile of PRS). We observed a greater effect of rare variants on the QTc among individuals with a higher polygenic risk (lowest PRS tertile: $\Delta Q T c_{\text {carrier/non-carrier }}=4.8 \mathrm{~ms}[-1.2-10.7]$; highest PRS tertile: $\Delta Q T c_{\text {carrier/non-carrier }}=18.9 \mathrm{~ms}$ [12.8-25.1];p-interaction=0.001).

Conclusions: QTc duration is influenced by both rare variants in established LQTS genes and polygenic risk. The phenotypic expression of monogenic variation is modulated by polygenic variation. Nevertheless, over $80 \%$ of individuals with prolonged QTc do not carry a rare monogenic variant or polygenic risk equivalent. 
medRxiv preprint doi: https://doi.org/10.1101/2021.06.18.21258578; this version posted June 21, 2021. The copyright holder for this preprint (which was not certified by peer review) is the author/funder, who has granted medRxiv a license to display the preprint in perpetuity.

It is made available under a CC-BY-NC-ND 4.0 International license.

\section{Condensed Abstract}

The QT interval duration is a well-established marker of sudden cardiac death. We examined the joint contribution of monogenic and polygenic variation to QT interval duration. Among individuals with pronounced QTc prolongation $(>480 \mathrm{~ms}), 1$ in 6 carried either a monogenic rare variant in a LQTS gene or had a PRS in the top decile, and over $80 \%$ had no identified genetic risk. Additionally, we found that polygenic risk modulates the phenotypic expression of putative pathogenic rare variants in LQTS genes, with a greater effect of rare variants on the QTc observed among individuals with a greater polygenic risk.

\section{Keywords \\ QT interval, Polygenic, Monogenic, Long QT Syndrome, Sudden Cardiac Death}


medRxiv preprint doi: https://doi.org/10.1101/2021.06.18.21258578; this version posted June 21, 2021. The copyright holder for this preprint (which was not certified by peer review) is the author/funder, who has granted medRxiv a license to display the preprint in perpetuity.

It is made available under a CC-BY-NC-ND 4.0 International license.

List of Abbreviations

ECG: Electrocardiogram

GWAS: Genome-Wide Association Study

LOF: Loss-Of-Function

LOFTEE: Loss-Of-Function Transcript Effect Estimator

LQTS: Long QT Syndrome

MAF: Minor Allele Frequency

NHLBI: National Heart Lung and Blood Institute

PRS: Polygenic Risk Score

TOPMed: TransOmics for Precision Medicine

UKBB: United Kingdom Biobank

WGS: Whole-Genome Sequencing 
medRxiv preprint doi: https://doi.org/10.1101/2021.06.18.21258578; this version posted June 21, 2021. The copyright holder for this preprint (which was not certified by peer review) is the author/funder, who has granted medRxiv a license to display the preprint in perpetuity.

It is made available under a CC-BY-NC-ND 4.0 International license .

\section{Introduction}

Perturbation of pathways involved in cardiac repolarization can lead to significant prolongation of the electrocardiographic QT interval with associated risks of cardiac arrhythmias and sudden cardiac death. ${ }^{1}$ While multiple extrinsic factors such as medications, hormones and serum electrolytes influence cardiac ion channels, rare variants within genes encoding subunits that comprise these channels (e.g., $K C N Q 1, K C N H 2$, and $S C N 5 A$ ) and other proteins are implicated in the long QT syndrome (LQTS). Recently, common genetic variants have been implicated in QT interval duration as well via genome wide association studies (GWAS), and the additive polygenic contributions of common variants are estimated to explain $\sim 8-10 \%$ of variation in the QT interval in the general population. ${ }^{2}$ However, the joint contribution of rare monogenic and common polygenic variation to the QT interval in the general population remains unknown.

Previous studies have examined the interaction between a limited number of common variants and monogenic rare variants in patients with established LQTS. ${ }^{3-6}$ We leverage two unique large population-based biobanks (United Kingdom Biobank (UKBB) and Trans-Omics for Precision Medicine (TOPMed)), to comprehensively examine the joint contributions of monogenic and polygenic variation to QT interval duration and the role of polygenic variation in modulating phenotypic expression of rare monogenic variation.

\section{Methods}

\section{Study Design and Patient Population}

\section{United Kingdom Biobank Cohort}

The UKBB is a prospective cohort of $\sim 500,000$ individuals from the UK with deep phenotyping and multiple genomic data types. ${ }^{7}$ Among participants with ECG data in the UKBB, we defined independent derivation and validation sub-cohorts for the heart-rate corrected QT interval (QTc) polygenic risk score (PRS). Two types of ECGs used in this analysis were performed on partially 
medRxiv preprint doi: https://doi.org/10.1101/2021.06.18.21258578; this version posted June 21, 2021. The copyright holder for this preprint (which was not certified by peer review) is the author/funder, who has granted medRxiv a license to display the preprint in perpetuity.

It is made available under a CC-BY-NC-ND 4.0 International license .

overlapping subsets of the UKBB: supine resting 12-lead ECGs $(\mathrm{N}=42,635)$ and 3-lead resting ECGs prior to a bicycle exercise protocol $(\mathrm{N}=60,799)$. Individuals who underwent both 12-lead and 3-lead ECGs $(\mathrm{N}=7,844)$ were only included in the validation sub-cohort and their QT interval was extracted from the 12-lead ECGs for this study. Heart rate corrected QT intervals were calculated using the Bazett formula, defined as QTc $=\frac{Q T(m s)}{\sqrt{R R}(s)}$ (Supplemental Methods).

The derivation sub-cohort included participants from the UKBB with both imputed genomic data and the pre-exercise ECG data only. We excluded individuals with poor quality genetic data and with characteristics that would affect their QT interval such as Wolff-ParkinsonWhite Syndrome, a paced rhythm, QRS interval >120 ms, digoxin use or class I or III antiarrhythmic drug use. Individuals with $2^{\text {nd }}$ or $3^{\text {rd }}$ degree AV block and those with extreme heart rates, $<40$ or $>120$ beats per minute, were also excluded (Supplemental Figure 1A). The final derivation sub-cohort consisted of 44,979 individuals.

The validation sub-cohort included participants from the UKBB with both imputed genomic data and QTc interval calculated from the resting 12-lead ECG. Again, we excluded participants with poor quality genetic data, and with characteristics that would affect their QT interval, which resulted in a validation sub-cohort comprising 39,800 individuals (Supplemental Figure 1A). Use of UKBB data was performed under application number 17488 and was approved by the local Massachusetts General Hospital institutional review board.

\section{Trans-Omics for Precision Medicine Cohort}

The TOPMed cohort included participants from the National Heart Lung and Blood Institute's (NHLBI) TOPMed program with both whole-genome sequencing (WGS) and QTc interval calculated $(\mathrm{N}=29,511)$. The study sample consisted of participants from 9 NHLBI cardiovascular cohorts (Supplemental Methods). In brief, we excluded participants with poor quality genetic 
medRxiv preprint doi: https://doi.org/10.1101/2021.06.18.21258578; this version posted June 21, 2021. The copyright holder for this preprint (which was not certified by peer review) is the author/funder, who has granted medRxiv a license to display the preprint in perpetuity.

It is made available under a CC-BY-NC-ND 4.0 International license .

data, and with characteristics that would affect their QT interval as detailed above. The final

TOPMed study sample included 26,976 individuals (Supplemental Figure 1B). All participants

provided written informed consent, and all participating studies obtained study approval from their local institutional review boards (Supplemental Methods).

\section{Rare Variant Annotation in TOPMed}

WGS quality control was performed on TOPMed data included in Freeze 6. Details of sequencing methods, variant calling and initial sequencing data quality control have been previously described by the TOPMed Informatics Research Center. ${ }^{8}$ Rare variant annotation methods are summarized in detail in the Supplemental Methods. We defined putative pathogenic rare variants as those classified as pathogenic or likely pathogenic in $\mathrm{Clin} \mathrm{ar}^{9}$, or that were classified as high confidence loss-of-function rare variants (minor allele frequency $(\mathrm{MAF})<$ 0.01) in canonical transcripts using Loss-Of-Function Transcript Effect Estimator (LOFTEE) ${ }^{10}$. LOF variants within $S C N 5 A$ were excluded as they are mechanistically not expected to be associated with prolongation of the QT interval. After subsetting to pathogenic/likely pathogenic variants and high confidence loss-of-function (LOF) variants in canonical transcripts, we identified 160 carriers of rare putative pathogenic variants in 10 LQTS genes $(K C N Q 1, K C N H 2$, SCN5A, KCNJ2, KCNE2, CACNA1C, CAV3, TRDN, CALM3, ANK2) included in a commercial (Invitae) LQTS panel in the TOPMed cohort.

\section{Statistical Analysis}

In the UKBB derivation sub-cohort, we performed a common variant (MAF $\geq 0.01$ ) GWAS for baseline pre-exercise QTc using SAIGE ${ }^{11}$ adjusting for age, genetically determined sex, beta blocker use, calcium channel blocker use, history of myocardial infarction, history of heart failure, genotyping array and principal components 1-12 of genetic ancestry. Thirty candidate 
medRxiv preprint doi: https://doi.org/10.1101/2021.06.18.21258578; this version posted June 21, 2021. The copyright holder for this preprint (which was not certified by peer review) is the author/funder, who has granted medRxiv a license to display the preprint in perpetuity. It is made available under a CC-BY-NC-ND 4.0 International license .

polygenic risk scores for the QTc interval were derived using a pruning and thresholding approach in Plink 1.9 (30 permutations of $\mathrm{p}$-value and $\mathrm{r}^{2}$ thresholds were used; $\mathrm{p}$-value thresholds: $1.0,0.5,0.05,5 \times 10^{-4}, 5 \times 10^{-6}$, and $5 \times 10^{-8} ; \mathrm{r}^{2}$ thresholds: $\left.0.05,0.2,0.4,0.6,0.8\right)$ on the results of the discovery GWAS. In the validation sub-cohort, we then selected the PRS with the largest improvement in $\mathrm{R}^{2}$ over the clinical model including age, genetically determined sex, beta blocker use, calcium channel blocker use, history of heart failure, history of myocardial infarction, and principal components 1-12 of genetic ancestry. The top PRS was then used to calculate PRS values for each individual in the TOPMed cohort (Figure 1). Derivation of a new PRS for the QTc interval in the UKBB was necessary to avoid overfitting that would be induced by using prior available genetic risk scores ${ }^{12}$ and GWAS results ${ }^{2}$ which were derived from studies that overlapped with our TOPMed cohort.

We examined the joint contribution of monogenic and polygenic variation to the QTc interval in TOPMed. Correlation between the derived QTc PRS and the QTc interval was assessed using Pearson's correlation coefficient. We tested the association between the QTc PRS and putative pathogenic rare variants with the QTc interval using multiple linear regression with adjustment for age, sex, beta blocker use, calcium channel blocker use, and principal components 1-12 of genetic ancestry. We collapsed putative pathogenic variants by gene and defined two groups of rare variant carriers, the first including carriers of putative pathogenic rare variants in any LQTS gene $(\mathrm{N}=160)$ and the second constrained to carriers of putative pathogenic rare variants within the three LQTS genes $(\mathrm{N}=58)$ for which there is definitive evidence for classic LQTS $(K C N Q 1, K C N H 2$, and $S C N 5 A) .{ }^{13}$ Additionally, given the autosomal recessive inheritance pattern associated with $T R D N$ variants in LQTS, we performed a sensitivity analysis in which only homozygous/compound heterozygous carriers of TRDN variants were classified as putative pathogenic rare variant carriers $(\mathrm{N}=72)$. 
medRxiv preprint doi: https://doi.org/10.1101/2021.06.18.21258578; this version posted June 21, 2021. The copyright holder for this preprint (which was not certified by peer review) is the author/funder, who has granted medRxiv a license to display the preprint in perpetuity. It is made available under a CC-BY-NC-ND 4.0 International license .

We then stratified the TOPMed cohort based on putative pathogenic rare variant carrier status and examined the association between the QTc PRS and QTc among carriers and noncarriers of rare variants. We tested for effect modification between QTc PRS and putative pathogenic rare variant carrier status using multiple linear regression adjusting for age, sex, beta blocker use, calcium channel blocker use, and principal components 1-12 of genetic ancestry. To examine whether effect modification between PRS and putative pathogenic rare variants was driven by previously identified common genetic modifiers ${ }^{3-5}$ in NOSIAP or KCNE1, or by common variants with strong effect sizes, we repeated the above analysis in TOPMed using a PRS calculated after excluding common variants in NOS1AP or KCNE1, and a PRS omitting the top $10 \%$ of common variants by effect size, respectively. Furthermore, we tested for effect modification using a PRS excluding common variants within a $\pm 1 \mathrm{MB}$ window from each LQTS gene assuming that such variants may modulate expression of each LQTS gene or otherwise affect the gene product. All statistical analyses were performed using R version 4.0.2 (R, Core Team 2020) unless otherwise specified. A two-sided p-value $<5 \times 10^{-8}$ was used to identify genome-wide significant common variants. For the remaining statistical analyses two-sided pvalues $<0.05$ were considered statistically significant.

\section{Results}

\section{UKBB Cohort}

The characteristics of the UKBB derivation and validation sub-cohorts were overall similar with few notable differences (Table 1). Individuals in the derivation sub-cohort were younger than those in the validation sub-cohort (mean age $52.7 \pm 5.8$ vs. $63.7 \pm 7.8$ years, respectively). Additionally, individuals in the derivation sub-cohort had a faster heart rate and shorter QT and QTc intervals as compared to individuals in the validation sub-cohort. While individuals of European ancestry constituted the majority of individuals in both the derivation and validation 
medRxiv preprint doi: https://doi.org/10.1101/2021.06.18.21258578; this version posted June 21, 2021. The copyright holder for this preprint (which was not certified by peer review) is the author/funder, who has granted medRxiv a license to display the preprint in perpetuity.

It is made available under a CC-BY-NC-ND 4.0 International license .

sub-cohorts, the derivation sub-cohort had a higher proportion of individuals of non-European ancestry (9.4\% vs. $3.2 \%)$.

In the QTc interval GWAS in the derivation sub-cohort, we identified 20 independent loci that exceeded genome-wide significance (Figure 2). We replicated 16 loci previously reported to be associated with the QTc interval and identified 4 novel loci (TOGARAM2, FAM13B, CHD2 and ZNF358) (Supplemental Tables 1, 2). There was no evidence of genomic inflation ( $\lambda=1.08$, Supplemental Figure 2). In TOPMed we replicated the association at the ZNF358 locus with the QTc interval (p-value=3.7 $\times 10^{-7}$ ) (Supplemental Table 3).

Utilizing the GWAS results we generated 30 candidate PRS in the derivation cohort using pre-specified pruning and thresholding cut-offs and comparatively assessed their performance in the validation cohort. The best performing PRS in the validation cohort comprised 565 variants (linkage disequilibrium $\mathrm{r}^{2} \leq 0.6$ and $\mathrm{p}<5 \times 10^{-4}$ ) and had an $\mathrm{R}^{2}$ of 0.11 in the multivariable model including the PRS, age, genetically determined sex, beta blocker use, calcium channel blocker use, history of heart failure, history of myocardial infarction and principal components 1-12 of genetic ancestry (Supplemental Table 4).

\section{TOPMed Cohort}

Ancestral diversity was more prominent in TOPMed as compared to the UKBB. Individuals of European $(\mathrm{N}=16,074,59.6 \%)$ and African $(\mathrm{N}=4,887,18.1 \%)$ ancestries constituted the largest ancestry groups in the TOPMed cohort. There was a substantial degree of admixture, with genetically-inferred ancestry unable to be determined for 3,653 (13.5\%) individuals. The study population mean QT duration was $408.4 \pm 31.6 \mathrm{~ms}$ and mean QTc duration was $423.8 \pm 22.9 \mathrm{~ms}$

\section{(Table 1).}

The QTc polygenic risk score, derived and validated in the UKBB and comprising 565 common variants, was normally distributed in TOPMed and was significantly associated with the 
medRxiv preprint doi: https://doi.org/10.1101/2021.06.18.21258578; this version posted June 21, 2021. The copyright holder for this preprint (which was not certified by peer review) is the author/funder, who has granted medRxiv a license to display the preprint in perpetuity. It is made available under a CC-BY-NC-ND 4.0 International license .

QTc interval (Pearson correlation coefficient $0.08,95 \%$ CI $0.07-0.09$; p-value $=2.5 \times 10^{-38}$ )

(Supplemental Figure 3). Following adjustment for age, sex, beta blocker use, calcium channel blocker use, and principal components 1-12 of genetic ancestry, the QTc PRS remained significantly associated with the QTc interval $(\Delta \mathrm{QTc} /$ decile of PRS $=0.9 \mathrm{~ms}, 95 \% \mathrm{CI} 0.8-1.0$; $\mathrm{p}$ value $\left.=1.1 \times 10^{-64}\right)$.

We collapsed putative pathogenic rare variant carrier status into two categories: (1) carriers of rare variants in any of the 10 LQTS genes $(\mathrm{N}=160)$ and $(2)$ carriers of rare variants in $K C N Q 1, K C N H 2$ or $S C N 5 A(\mathrm{~N}=58)$. In multivariable analyses, carriers of putative pathogenic rare variants in any of the 10 LQTS genes and those who were carriers of putative pathogenic rare variants in $K C N Q 1, K C N H 2$ or $S C N 5 A$ had a $10.9 \mathrm{~ms}\left(95 \% \mathrm{CI}, 7.4-14.4\right.$, p-value $\left.=1.1 \times 10^{-9}\right)$ and $26.5 \mathrm{~ms}\left(95 \% \mathrm{CI}, 20.7\right.$ - 32.3, p-value $\left.=4.7 \times 10^{-19}\right)$ increase in their QTc interval, respectively, as compared to non-carriers (Supplemental Table 5). After excluding heterozygous carriers of $T R D N$ rare variants, carriers of putative pathogenic rare variants in any of the 10 LQTS genes had a $22.7 \mathrm{~ms}\left(95 \% \mathrm{CI}, 17.5-27.9\right.$, p-value $\left.1.2 \times 10^{-17}\right)$ increase in their QTc interval as compared to non-carriers.

We then examined the distribution of polygenic and monogenic risk across the spectrum of QTc intervals in the study population to assess the contribution of genetic determinants to the QTc interval. To approximate monogenic and polygenic risk, we categorized the polygenic risk score into two categories (highest decile vs. lower $90^{\text {th }}$ percentile). The mean difference in QTc interval between the top and lowest PRS deciles $(8.1 \mathrm{~ms})$ approximates the delta QTc observed among carriers of putative pathogenic rare variants in LQTS genes compared to non-carriers. Across increasing strata of QTc intervals in the population, there was a consistent increase in the proportion of individuals with a PRS in the top decile $\left(\mathrm{p}\right.$-trend $\left.=3.8 \times 10^{-27}\right)$ and the proportion of individuals who were carriers of monogenic putative pathogenic rare variants in LQTS genes (ptrend $=4.1 \times 10^{-14}$ ) (Figure 3). However, we found that only 3.4\% of individuals with pronounced 
medRxiv preprint doi: https://doi.org/10.1101/2021.06.18.21258578; this version posted June 21, 2021. The copyright holder for this preprint (which was not certified by peer review) is the author/funder, who has granted medRxiv a license to display the preprint in perpetuity.

It is made available under a CC-BY-NC-ND 4.0 International license .

QTc prolongation (>480 ms) carried a monogenic rare variant in a LQTS gene, $13.6 \%$ had a polygenic risk score in the top decile and $16.7 \%$ had either a monogenic rare variant or a polygenic risk score in the top decile (Figure 3). Thus, over $80 \%$ of individuals with pronounced QTc prolongation (>480 ms) do not have an identified rare genetic variant or burden of polygenic risk equivalent to a monogenic variant to explain the QTc prolongation. Following exclusion of heterozygous carriers of $T R D N$ variants from the putative pathogenic rare variant carrier group, 3.1\% of individuals with pronounced QTc prolongation (>480 ms) were carriers of a monogenic rare variant.

Next, we assessed for effect modification between polygenic risk and putative pathogenic rare variant carrier status. Across strata of carrier status for putative pathogenic rare variants in LQTS genes, the QTc polygenic risk score was associated with a larger increase in the QTc interval in carriers $(\Delta \mathrm{QTC} /$ decile of PRS $=2.0 \mathrm{~ms}, 95 \% \mathrm{CI} 0.2-3.8 ; \mathrm{p}$-value $=0.03)$ as compared to non-carriers $\left(\Delta \mathrm{QTc} /\right.$ decile of PRS $=0.9 \mathrm{~ms}, 95 \% \mathrm{CI} 0.8-1.0 ; \mathrm{p}$-value $\left.=3.9 \times 10^{-64}\right)(\mathrm{p}-$ interaction=0.005; Figure 4A). The effect was more pronounced among carriers of putative pathogenic rare variants confined to $K C N Q 1, K C N H 2$ and $S C N 5 A$ where the QTc on average increased by $5.8 \mathrm{~ms}$ per decile of the PRS ( $\triangle \mathrm{QTC}$ /decile of PRS $=5.8 \mathrm{~ms}, 95 \% \mathrm{CI} 1.6-9.9$; pvalue $=0.008)(\mathrm{p}$-interaction $=0.01$; Figure 4B). Consistent with the above findings, we found evidence of effect modification by the PRS on the association of putative pathogenic rare variant carrier status with the extent of QTc prolongation. QTc prolongation associated with putative pathogenic rare variants in LQTS genes consistently increased across increasing tertiles of the polygenic risk score (lowest PRS tertile: $\Delta \mathrm{QT} \mathrm{c}_{\text {carrier/non-carrier }}=4.8 \mathrm{~ms}[-1.2$ - 10.7]; intermediate PRS tertile: $\Delta Q T c_{c a r r i e r / n o n-c a r r i e r}=9.4 \mathrm{~ms}$ [3.5 - 15.4]; highest PRS tertile: $\Delta Q T c_{\text {carrier/non-carrier }=18.9}$ ms [12.8 - 25.1]; p-interaction=0.001). A similar pattern was observed when examining putative pathogenic rare variants in the three genes with definitive evidence for typical $\operatorname{LQTS}^{13}$ (p- 
medRxiv preprint doi: https://doi.org/10.1101/2021.06.18.21258578; this version posted June 21, 2021. The copyright holder for this preprint (which was not certified by peer review) is the author/funder, who has granted medRxiv a license to display the preprint in perpetuity. It is made available under a CC-BY-NC-ND 4.0 International license .

interaction=0.006) (Figure 5) and after excluding heterozygous carriers of $T R D N$ rare variants (Supplemental Figure 4).

Most carriers $(80.6 \%)$ and non-carriers $(93.4 \%)$ of putative pathogenic rare variants in LQTS genes had normal QTc durations (<460 ms). Among carriers of putative pathogenic rare variants with prolonged QTc interval ( $\geq 460 \mathrm{~ms}$ ), we observed a 2-fold enrichment in the odds for high polygenic risk as compared to carriers with normal QTc interval ( $<460 \mathrm{~ms})$. Conversely, there was only a 1.2-fold enrichment in the odds for high polygenic risk among non-carriers of putative pathogenic rare variants with prolonged vs. normal QTc interval (Figure 6). Notably, $73 \%$ of putative pathogenic rare variant carriers with normal QTc $<460 \mathrm{~ms}$ had low/intermediate polygenic risk which potentially contributes to their normal QTc interval despite carrying a putative pathogenic rare variant in a LQTS gene.

To explore potential mediators of the observed effect modification of the PRS on the association of putative pathogenic rare variants with the QTc interval, we performed a number of sensitivity analyses. First, after excluding common variants in previously described genetic modifiers of LQTS (NOS1AP and KCNE1), our findings remained unchanged suggesting that additional distinct variants underlie the observed effect modification (Supplemental Figure 5A). Second, following omission of common variants within $\pm 1 \mathrm{MB}$ from the 10 evaluated LQTS genes from the PRS, which we assume capture most of the regulatory variation likely to influence gene expression, the interaction between the polygenic risk and putative pathogenic rare variant carrier status persisted (Supplemental Figure 5B). Third, exclusion of the top 10\% of common variants by effect size to assess whether our findings were mediated by the top common variants most strongly associated with the QTc interval did not alter our findings (Supplemental Figure 5C). Additionally, we note that carriers of rare variants in each of the 10 LQTS genes were randomly distributed across the spectrum of polygenic risk in the study sample (Supplemental Figure 6) and thus the identified interaction is not mediated by non-random 
medRxiv preprint doi: https://doi.org/10.1101/2021.06.18.21258578; this version posted June 21, 2021. The copyright holder for this preprint (which was not certified by peer review) is the author/funder, who has granted medRxiv a license to display the preprint in perpetuity.

It is made available under a CC-BY-NC-ND 4.0 International license .

clustering of carriers of rare variants in a particular gene across the polygenic risk distribution.

Lastly, we performed a stratified analysis by European vs. non-European ancestry in TOPMed and found an overall consistent pattern of effect modification between the PRS and putative pathogenic rare variants in LQTS genes (beta for interaction $1.23,95 \% \mathrm{CI}(-0.30-2.75)$ and $1.20,95 \%$ CI (-0.96 - 3.35) for European and non-European ancestry, respectively); power was limited by the small sample size of putative pathogenic rare variant carriers in each ancestral group (Supplemental Figure 7).

\section{Discussion}

In this analysis comprising 26,976 multi-ancestry individuals from population-based cohort studies, we demonstrate evidence of a synergistic effect of common and rare variants on the QTc interval. Approximately 1 in 6 individuals with marked QTc prolongation beyond $480 \mathrm{msec}$ carried a rare or large-effect polygenic variant equivalent - putative pathogenic rare variants were rare and carried in just over $3 \%$ of such individuals, whereas nearly $14 \%$ were in the top decile of polygenic risk. Notably, 4 out of 5 carriers of putative pathogenic rare variants in LQTS genes had a normal QTc - below $460 \mathrm{~ms}$ - consistent with concealed LQTS, ${ }^{14}$ and the odds of QTc prolongation among putative pathogenic rare variant carriers was increased 2-fold among individuals with a high background of polygenic risk. Our findings demonstrate that the magnitude of QTc prolongation among monogenic rare variant carriers is modulated by polygenic risk.

\section{Genetic Determinants of the QT Interval}

The QT interval is a complex and dynamic heritable trait with both monogenic and polygenic determinants. ${ }^{2,15}$ Heritability estimates in unselected community-based populations range from 30-40\%. ${ }^{16}$ Comprehensive genetic evaluation of individuals with QTc prolongation without other 
medRxiv preprint doi: https://doi.org/10.1101/2021.06.18.21258578; this version posted June 21, 2021. The copyright holder for this preprint (which was not certified by peer review) is the author/funder, who has granted medRxiv a license to display the preprint in perpetuity.

It is made available under a CC-BY-NC-ND 4.0 International license .

criteria for LQTS may identify a small subset with a possible genetic explanation for the QTc prolongation. Indeed, nearly 1 in 6 individuals with marked QTc prolongation, defined as QTc > $480 \mathrm{msec}$, carried a putative pathogenic rare variant in a LQTS gene or high polygenic risk equivalent in this study with a larger contribution from polygenic risk.

Current clinical genetic testing for evaluation of prolonged QTc interval is focused on identification of rare putative pathogenic variants in LQTS genes. ${ }^{14}$ Our findings highlight the sizeable genetic contribution of common variant polygenic risk and its role in comprehensive assessment of genetic determinants of the QTc. Nevertheless, over $80 \%$ of individuals with prolonged QTc interval did not carry a monogenic putative pathogenic rare variant or a polygenic risk equivalent in this study. Our findings support the possibility that additional genetic contributions to QTc interval duration remain undiscovered. Future increasingly largescale common and rare variant population-based association studies of the QTc interval may shed light on additional novel genetic determinants of the QTc interval.

\section{Polygenic Risk and Susceptibility to QTC Prolongation}

In this study, we show a 4-fold increase in the magnitude of QTc prolongation associated with putative pathogenic rare variants among individuals with high polygenic risk as compared to those with low polygenic risk ( $\triangle \mathrm{QTc} 18.9$ vs. $4.8 \mathrm{~ms}$ ). Additionally, putative pathogenic rare variant carriers with prolonged QTc $\geq 460 \mathrm{~ms}$ had a 2 -fold higher odds of high background polygenic risk as compared to those with QTc intervals <460 ms. With enhanced access to sequencing methods in clinical settings and genomic sequence data emerging from large-scale biobanks, increasingly more unaffected carriers of putative pathogenic rare variants in LQTS genes will come to attention. Our findings demonstrate the role of polygenic risk in modulating phenotypic expression of putative pathogenic rare variants in LQTS genes and may inform why some carriers exhibit QTc prolongation and others do not. 
medRxiv preprint doi: https://doi.org/10.1101/2021.06.18.21258578; this version posted June 21, 2021. The copyright holder for this preprint (which was not certified by peer review) is the author/funder, who has granted medRxiv a license to display the preprint in perpetuity.

It is made available under a CC-BY-NC-ND 4.0 International license .

The mechanisms by which polygenic risk modulates the phenotypic expression of putative pathogenic rare variants in LQTS genes remains poorly understood. Repolarization reserve reflects redundancies in biological pathways that govern cardiac repolarization and protect against marked QT prolongation from a single pathologic insult. ${ }^{1}$ Akin to the "multiplehit" hypothesis in cancer biology, pathologic prolongation of the QTc interval occurs in the presence of multiple lesions that converge and significantly impinge on repolarization reserve. Polygenic risk scores of the QTc interval offer an opportunity to collectively assess multiple biologic pathways involved in cardiac repolarization and may serve as a genetic surrogate for repolarization reserve hence, capturing an individual's susceptibility to QTc prolongation in the presence of a putative pathogenic rare variant in an LQTS gene.

Previous studies have demonstrated that polygenic risk may have important implications for determining susceptibility to QT prolonging drugs as well as expressivity of the LQTS phenotype. A study demonstrated the utility of a QTc PRS, comprising 61 variants, in predicting the variability in QTc prolongation associated with different anti-arrhythmic drugs and the associated risk of Torsade des Pointes. ${ }^{12}$ Additionally, QTc polygenic risk has been shown to be higher on average among LQTS cases, as compared to controls, further highlighting the contribution of polygenic risk to disease susceptibility. ${ }^{17}$

\section{Genetic Modifiers and Long QT Syndrome Genes}

Studies of LQTS families have revealed incomplete penetrance of LQTS. ${ }^{18}$ A number of studies have investigated individual common genetic modifiers associated with the QT interval that may underlie incomplete penetrance and variable expressivity in cohorts of patients with LQTS. ${ }^{3-6}$ Common variants in NOSIAP, a gene identified to be strongly associated with the QT interval in the general population ${ }^{2}$, have been shown to influence phenotype expression and outcomes in LQTS populations. ${ }^{3,4} K C N E 1-D 85 N$ a common polymorphism in $K C N E 1$, has been reported to 
medRxiv preprint doi: https://doi.org/10.1101/2021.06.18.21258578; this version posted June 21, 2021. The copyright holder for this preprint (which was not certified by peer review) is the author/funder, who has granted medRxiv a license to display the preprint in perpetuity.

It is made available under a CC-BY-NC-ND 4.0 International license .

be more prevalent among patients with congenital LQTS and individuals with acquired druginduced LQTS as compared to healthy controls. ${ }^{5}$ A number of other genetic modifiers of LQTS, including common variants in $A K A P 9, K C N H 2, K C N Q 1$ and $R E M 2$, have been also described in the literature. ${ }^{6}$

In this study we expand upon previous findings of single common variant genetic modifiers and demonstrate a role for common variant polygenic risk scores in modulating the magnitude of QTc prolongation imparted by pathogenic rare variation in genes known to be associated with LQTS. The effect modification of polygenic risk on phenotypic expression of putative pathogenic rare variants persisted following exclusion of common variants in previously described genetic modifiers (NOS1AP and KCNE1) and common variants with strong effect size, highlighting the incremental role of comprehensive common variant risk assessment using polygenic risk scores in capturing the interplay between common and rare variation. Additionally, exclusion of common variants within \pm 1 MB of LQTS genes did not alter our findings suggesting that effect modification is not solely driven by modulation of LQTS gene expression or their gene product. Further studies are needed to examine the biologic pathways and mechanisms underlying the observed effect modification.

\section{Polygenic and Monogenic Contribution to Other Genomic Disorders}

Recently, the interplay between monogenic and polygenic risk has been described for a number of genomic disorders. A contemporary study examining a spectrum of diseases including familial hypercholesterolemia, hereditary breast and ovarian cancer and Lynch syndrome found that polygenic risk explained more variation in disease risk among carriers vs. non-carriers of monogenic rare variants and aided in better risk estimation among carriers. ${ }^{19}$ Our group has previously reported higher penetrance of atrial fibrillation among TTN loss-of-function carriers within higher tertiles of polygenic risk of atrial fibrillation. ${ }^{20}$ Expanding these findings to carriers 
medRxiv preprint doi: https://doi.org/10.1101/2021.06.18.21258578; this version posted June 21, 2021. The copyright holder for this preprint (which was not certified by peer review) is the author/funder, who has granted medRxiv a license to display the preprint in perpetuity.

It is made available under a CC-BY-NC-ND 4.0 International license .

of monogenic rare variants in LQTS genes is of particular relevance given low penetrance in LQTS $^{18}$ and the implications of living with sudden cardiac death risk among carriers of putative pathogenic rare variants in LQTS genes.

\section{Limitations}

Our results should be interpreted in the context of the study design. The study findings apply to individuals who enrolled in the included population-based cohorts, and do not necessarily apply to patients seeking clinical evaluations for evident or possible LQTS. The TOPMed cohort did not ascertain LQTS diagnosis among study participants which prohibited performing an analysis examining the contribution of polygenic and monogenic risk to LQTS in the general population and our findings strictly apply to the QTc interval. Further population-based studies with LQTS phenotyping are needed to address this question. Additionally, despite studying a large multiancestry cohort from the UKBB to derive and validate our PRS, the population was predominantly of European ancestry which may not accurately characterize polygenic risk in the TOPMed cohort. However, in a sensitivity analysis, we found overall similar findings after stratifying the TOPMed cohort by European vs. non-European ancestry. Our analyses of monogenic variation focused on coding variants within established LQTS genes. Additional studies are needed to evaluate the contribution of non-coding rare variation, copy-number variation and structural variation to the QTc interval in the general population. This study focused on exploring genetic determinants of the QTc interval, however, multiple non-genetic factors contribute to the QTc interval, which we were unable to fully account for in this analysis. Lastly, further studies are needed to examine the impact of polygenic risk on clinical outcomes of carriers of monogenic rare variants in LQTS genes in the general population. 
medRxiv preprint doi: https://doi.org/10.1101/2021.06.18.21258578; this version posted June 21, 2021. The copyright holder for this preprint (which was not certified by peer review) is the author/funder, who has granted medRxiv a license to display the preprint in perpetuity.

It is made available under a CC-BY-NC-ND 4.0 International license .

\section{Conclusions}

QTc duration is influenced by both polygenic risk and rare variation in established LQTS genes.

Polygenic risk modulates the magnitude of QTc prolongation associated with monogenic rare variation in LQTS genes and may inform assessment of monogenic rare variant carriers in the general population. Nevertheless, over $80 \%$ of individuals with prolonged QTc intervals do not have a yet identified genetic risk factor to explain the QTc prolongation. Further studies are needed to uncover novel genetic determinants of the QTc interval and establish the role of polygenic risk assessment in clinical evaluation of monogenic rare variant carriers in LQTS genes in the general population.

\section{Perspectives}

Competency in Medical Knowledge: Population based QTc duration is influenced by both monogenic rare variation in established LQTS genes and polygenic risk, as well as non-genetic factors. One in 6 individuals with QTc > $480 \mathrm{~ms}$ have an identified genetic risk factor. Polygenic risk modulates the phenotypic expression of monogenic rare variants in established LQTS genes. Translational Outlook 1: QTc polygenic risk informs the assessment of monogenic rare variant carriers in LQTS genes in the general population and contributes to the understanding of why certain individuals who carry putative pathogenic rare variants in LQTS genes have prolonged QTc intervals and others do not.

Translational Outlook 2: The role of QTc polygenic risk in modulating penetrance in LQTS and cardiovascular outcomes among carriers of monogenic rare variants in LQTS genes in the general population should be investigated. 
medRxiv preprint doi: https://doi.org/10.1101/2021.06.18.21258578; this version posted June 21, 2021. The copyright holder for this preprint (which was not certified by peer review) is the author/funder, who has granted medRxiv a license to display the preprint in perpetuity. It is made available under a CC-BY-NC-ND 4.0 International license .

\section{References}

1. Roden DM, Yang T: Protecting the Heart Against Arrhythmias: Potassium Current Physiology and Repolarization Reserve. Circulation 2005; 112:1376-1378.

2. CARe Consortium, COGENT Consortium, DCCT/EDIC, et al.: Genetic association study of QT interval highlights role for calcium signaling pathways in myocardial repolarization. Nat Genet 2014; 46:826-836.

3. Crotti L, Monti MC, Insolia R, et al.: NOS1AP Is a Genetic Modifier of the Long-QT Syndrome. Circulation 2009; 120:1657-1663.

4. Tomás M, Napolitano C, De Giuli L, et al.: Polymorphisms in the NOS1AP gene modulate QT interval duration and risk of arrhythmias in the long QT syndrome. J Am Coll Cardiol 2010; 55:2745-2752.

5. Nishio Y, Makiyama T, Itoh H, et al.: D85N, a KCNE1 Polymorphism, Is a DiseaseCausing Gene Variant in Long QT Syndrome. Journal of the American College of Cardiology 2009; 54:812-819.

6. Schwartz PJ, Crotti L, George AL: Modifier genes for sudden cardiac death. European Heart Journal [Internet] 2018 [cited 2020 Nov 23]; . Available from:

https://academic.oup.com/eurheartj/advance-article/doi/10.1093/eurheartj/ehy502/5094987

7. Bycroft C, Freeman C, Petkova D, et al.: The UK Biobank resource with deep phenotyping and genomic data. Nature 2018; 562:203-209.

8. ToPMed. Available from: https://www.nhlbiwgs.org/topmed-whole-genome-sequencingmethods-freeze-6

9. Landrum MJ, Lee JM, Benson M, et al.: ClinVar: public archive of interpretations of clinically relevant variants. Nucleic Acids Res 2016; 44:D862-868.

10. Karczewski KJ, Francioli LC, Tiao G, et al.: The mutational constraint spectrum quantified from variation in 141,456 humans. Nature 2020; 581:434-443.

11. Zhou W, Nielsen JB, Fritsche LG, et al.: Efficiently controlling for case-control imbalance and sample relatedness in large-scale genetic association studies. Nat Genet 2018; 50:13351341.

12. Strauss DG, Vicente J, Johannesen L, et al.: Common Genetic Variant Risk Score Is Associated With Drug-Induced QT Prolongation and Torsade de Pointes Risk: A Pilot Study. Circulation 2017; 135:1300-1310.

13. Adler A, Novelli V, Amin AS, et al.: An International, Multicentered, Evidence-Based Reappraisal of Genes Reported to Cause Congenital Long QT Syndrome. Circulation 2020; 141:418-428.

14. Priori SG, Wilde AA, Horie M, et al.: HRS/EHRA/APHRS expert consensus statement on the diagnosis and management of patients with inherited primary arrhythmia syndromes: 
medRxiv preprint doi: https://doi.org/10.1101/2021.06.18.21258578; this version posted June 21, 2021. The copyright holder for this preprint (which was not certified by peer review) is the author/funder, who has granted medRxiv a license to display the preprint in perpetuity. It is made available under a CC-BY-NC-ND 4.0 International license .

document endorsed by HRS, EHRA, and APHRS in May 2013 and by ACCF, AHA, PACES, and AEPC in June 2013. Heart Rhythm 2013; 10:1932-1963.

15. Schwartz PJ, Crotti L, Insolia R: Long-QT Syndrome: From Genetics to Management. Circ Arrhythm Electrophysiol 2012; 5:868-877.

16. Newton-Cheh C, Larson MG, Corey DC, et al.: QT interval is a heritable quantitative trait with evidence of linkage to chromosome 3 in a genome-wide linkage analysis: The Framingham Heart Study. Heart Rhythm 2005; 2:277-284.

17. Lahrouchi N, Tadros R, Crotti L, et al.: Transethnic Genome-Wide Association Study Provides Insights in the Genetic Architecture and Heritability of Long QT Syndrome. Circulation 2020; 142:324-338.

18. Priori SG, Napolitano C, Schwartz PJ: Low Penetrance in the Long-QT Syndrome: Clinical Impact. Circulation 1999; 99:529-533.

19. Fahed AC, Wang M, Homburger JR, et al.: Polygenic background modifies penetrance of monogenic variants for tier 1 genomic conditions. Nat Commun 2020; 11:3635.

20. Choi SH, Jurgens SJ, Weng L-C, et al.: Monogenic and Polygenic Contributions to Atrial Fibrillation Risk. Circulation Research [Internet] Lippincott Williams \& Wilkins, 2020 [cited 2021 Jan 26]; . Available from: https://www.ahajournals.org/doi/abs/10.1161/CIRCRESAHA.119.315686 
medRxiv preprint doi: https://doi.org/10.1101/2021.06.18.21258578; this version posted June 21, 2021. The copyright holder for this preprint (which was not certified by peer review) is the author/funder, who has granted medRxiv a license to display the preprint in perpetuity. It is made available under a CC-BY-NC-ND 4.0 International license .

\section{Figure Legends.}

Figure 1. Study design and flowchart. GWAS: genome-wide association study; PRS: polygenic risk score; P+T: pruning and thresholding; TOPMed: Trans-Omics for Precision Medicine; UKBB: United Kingdom Biobank.

Figure 2. QTc interval genome-wide association results across 22 autosomes in the UKBB derivation sub-cohort. Nearest genes are used for annotation. The dashed grey line represents the threshold for genome-wide significance $\left(\mathrm{P}<5 \times 10^{-8}\right)$.

Figure 3. Top PRS Decile and Putative Pathogenic Rare Variant Carrier Distribution Across QTc Strata.

Figure 4. Variation in the Predicted QTc Across Percentiles of the Polygenic Risk Score stratified by Putative Pathogenic Rare Variant Carrier Status in all long QT Syndrome genes (A) and in $K C N Q 1, K C N H 2$ and $S C N 5 A(B)$.

Figure 5. Multivariable Association of Putative Pathogenic Rare Variant Carrier Status with QTc Interval Duration Across Tertiles of QTc Polygenic Risk Score. Low, intermediate and high PRS strata reflect first, second and third tertiles of the PRS in the study sample, respectively.

Figure 6. Distribution of Low/Intermediate and High Polygenic Risk in Individuals with Normal ( $<460 \mathrm{~ms})$ and Prolonged QTc Intervals $(\geq 460 \mathrm{~ms})$ among Carriers and non-Carriers of Putative Pathogenic Rare Variants in Long QT Syndrome genes. Low, intermediate and high PRS strata reflect first, second and third tertiles of the PRS in the study sample, respectively. 
Table 1. Characteristics of the UK Biobank and TOPMed Cohorts

\begin{tabular}{|c|c|c|c|}
\hline & $\begin{array}{c}\text { UKBB Derivation } \\
\text { Sub-cohort } \\
(\mathrm{N}=44,979) \\
\end{array}$ & $\begin{array}{c}\text { UKBB Validation } \\
\text { Sub-cohort } \\
(\mathbf{N}=\mathbf{3 9}, \mathbf{8 0 0}) \\
\end{array}$ & $\begin{array}{l}\text { TOPMed Cohort } \\
(\mathrm{N}=26,976)\end{array}$ \\
\hline Age (Years)* & $52.7 \pm 5.8$ & $63.7 \pm 7.8$ & $59.8 \pm 12.5$ \\
\hline Height $(\mathrm{cm})$ & $168.8 \pm 9.3$ & $169.6 \pm 9.2$ & $166.0 \pm 9.5$ \\
\hline Weight $(\mathrm{kg})^{*}$ & $79.2 \pm 15.2$ & $76.7 \pm 14.9$ & $79.5 \pm 18.9$ \\
\hline Male $(\%)$ & $22,197(49.3)$ & $19,018(47.8)$ & $17,644(65.4)$ \\
\hline \multicolumn{4}{|l|}{ Ancestry $(\mathrm{n},(\%))^{*}$} \\
\hline European & $40,766(90.6)$ & $38,546(96.8)$ & $16,074(59.6)$ \\
\hline African & $1,367(3.0)$ & $248(0.6)$ & $4,887(18.1)$ \\
\hline Admixed American & $66(0.1)$ & $12(0.03)$ & $596(2.2)$ \\
\hline East Asian & $320(0.7)$ & $150(0.4)$ & $715(2.7)$ \\
\hline South Asian & $809(1.8)$ & $221(0.6)$ & $53(0.2)$ \\
\hline Amish & -- & -- & $998(3.7)$ \\
\hline Undetermined & $1,651(3.8)$ & $623(1.6)$ & $3,653(13.5)$ \\
\hline Beta Blocker (n, (\%)) & $2,342(5.2)$ & $1,652(4.2)$ & $3,415(12.7)$ \\
\hline $\begin{array}{l}\text { Calcium Channel } \\
\text { Blocker }(\mathrm{n},(\%))\end{array}$ & $3,385(7.5)$ & $2,128(5.3)$ & $3,043(11.3)$ \\
\hline QRS duration (ms) & $87.9 \pm 11.6$ & $86.9 \pm 10.3$ & $89.6 \pm 10.2$ \\
\hline $\begin{array}{c}\text { Heart rate } \\
\text { (beats/minute)* }\end{array}$ & $71.1 \pm 11.7$ & $61.8 \pm 10.4$ & $65.9 \pm 11.1$ \\
\hline QT interval (ms)* & $381.6 \pm 29.0$ & $417 \pm 30.3$ & $408.4 \pm 31.6$ \\
\hline QTc interval (ms)* & $412.0 \pm 23.2$ & $419.9 \pm 22.8$ & $423.8 \pm 22.9$ \\
\hline
\end{tabular}

* Variables with standardized mean differences $>10 \%$ between the derivation and validation cohorts in the UKBB. 


\section{(1) Derivation Sub-cohort}

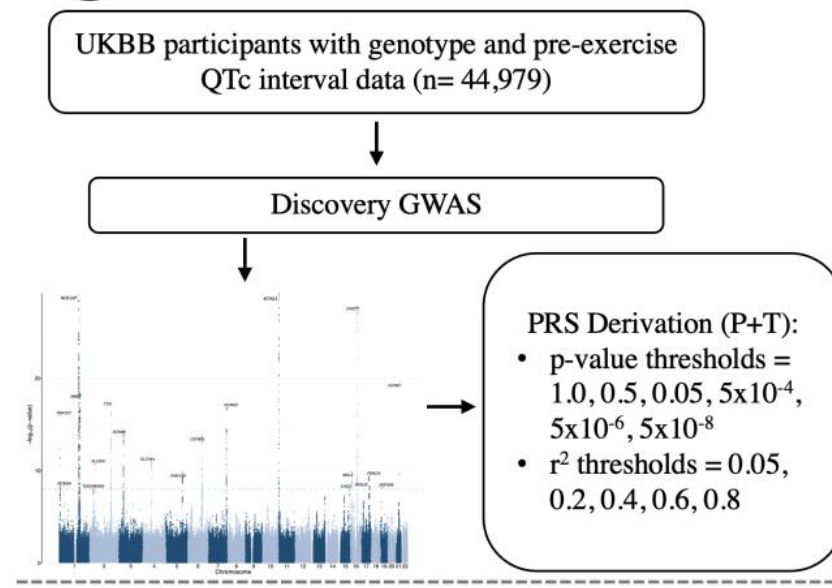

(2) Independent Validation Sub-cohort

UKBB participants with genotype and resting QTc interval data $(n=39,800)$

Assess performance of 30 derived candidate PRS

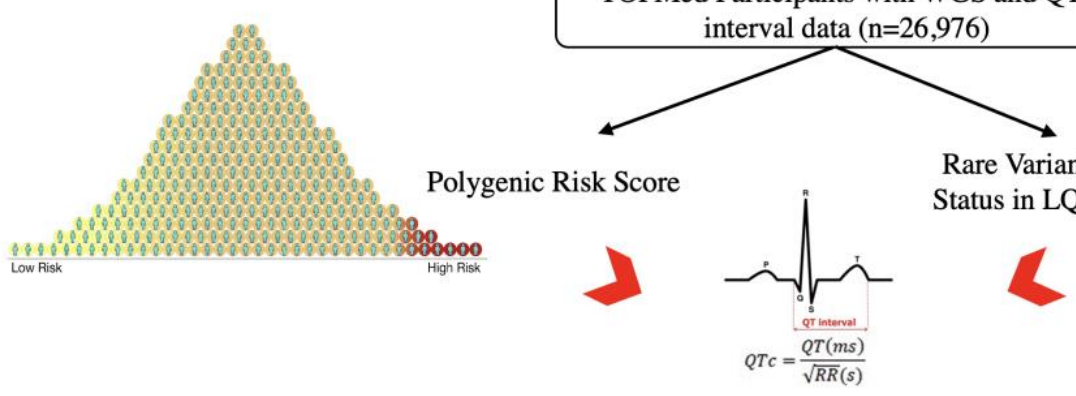

\section{TOPMed}

(3)

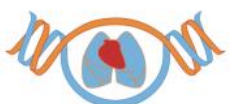

TOPMed Participants with WGS and QTc
interval data $(\mathrm{n}=26,976)$

Rare Variant Carrier Status in LQTS genes
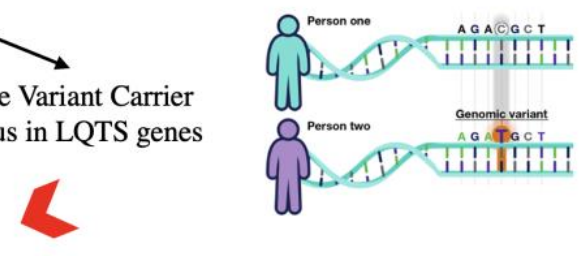

Figure 1. Study design and flowchart. GWAS: genome-wide association study; PRS: polygenic risk score; P+T: pruning and thresholding; TOPMed: Trans-Omics for Precision Medicine; UKBB: United Kingdom Biobank. 
medRxiv preprint doi: https://doi.org/10.1101/2021.06.18.21258578; this version posted June 21, 2021. The copyright holder for this preprint (which was not certified by peer review) is the author/funder, who has granted medRxiv a license to display the preprint in perpetuity.

It is made available under a CC-BY-NC-ND 4.0 International license .

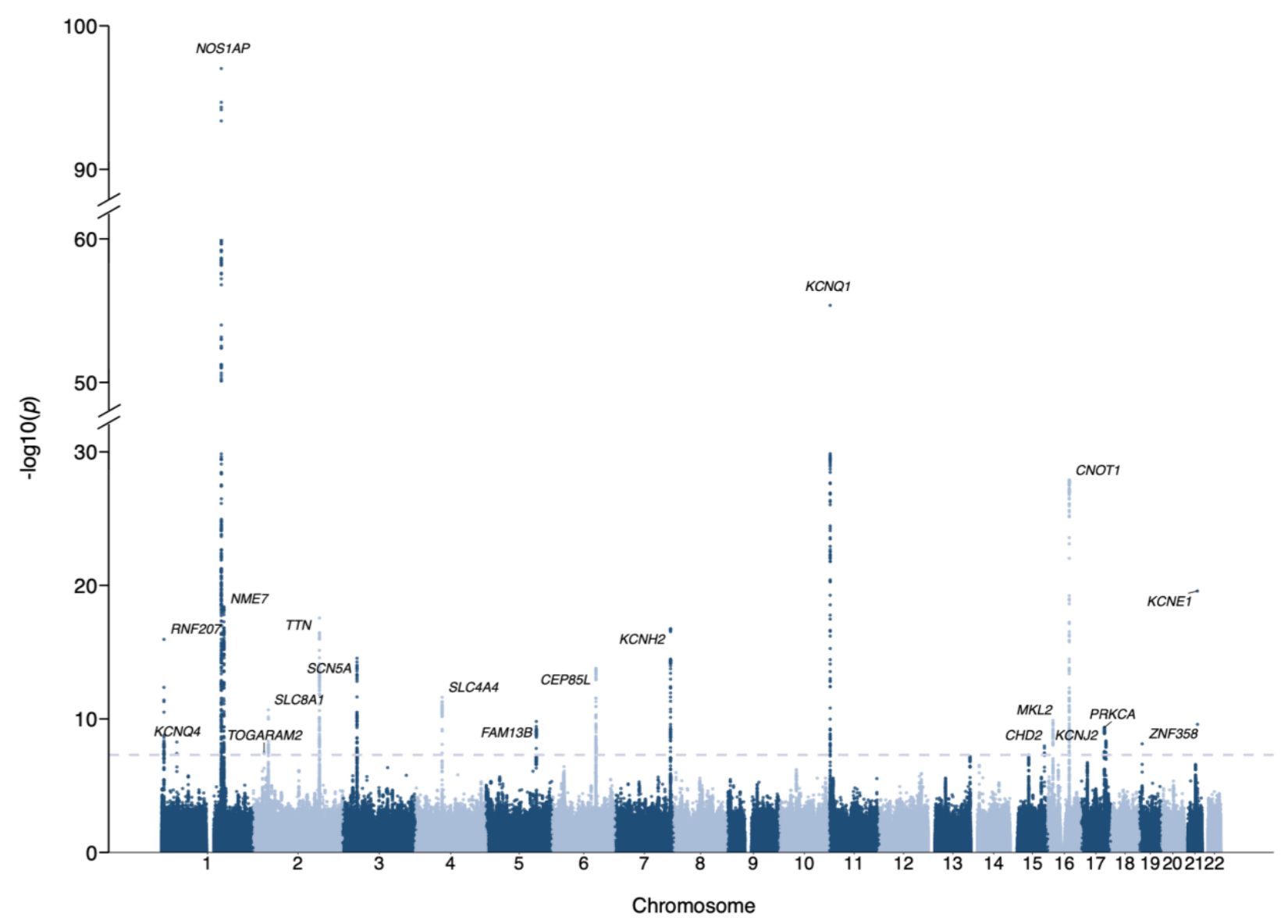

Figure 2. QTc interval genome-wide association results across 22 autosomes in the UKBB derivation sub-cohort. Nearest genes are used for annotation. The dashed grey line represents the threshold for genome-wide significance $\left(\mathrm{P}<5 \times 10^{-8}\right)$. 
medRxiv preprint doi: https://doi.org/10.1101/2021.06.18.21258578; this version posted June 21, 2021. The copyright holder for this preprint (which was not certified by peer review) is the author/funder, who has granted medRxiv a license to display the preprint in perpetuity.

It is made available under a CC-BY-NC-ND 4.0 International license .

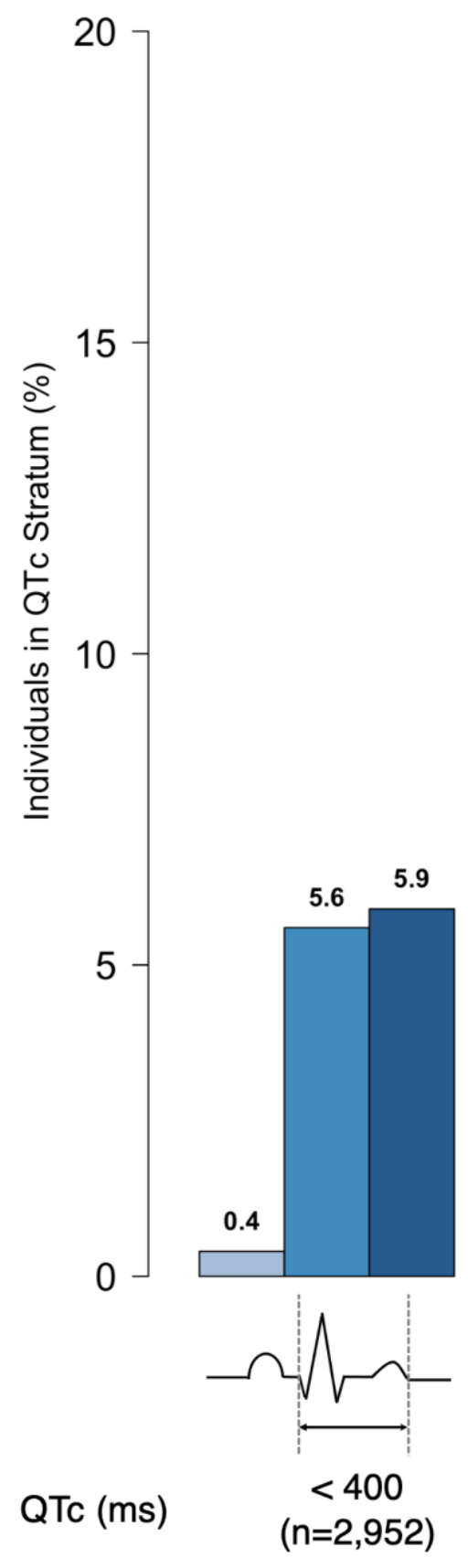

$\square$ Putative Pathogenic Rare Variant Carrier
$\square$ Top PRS Decile
$\square$ Top PRS Decile Or Putative Pathogenic Rare Variant Carrier

Figure 3. Top PRS Decile and Putative Pathogenic Rare Variant Carrier Distribution Across QTe Strata. 
medRxiv preprint doi: https://doi.org/10.1101/2021.06.18.21258578; this version posted June 21, 2021. The copyright holder for this preprint (which was not certified by peer review) is the author/funder, who has granted medRxiv a license to display the preprint in perpetuity.

It is made available under a CC-BY-NC-ND 4.0 International license.

A Predicted QTc Across Percentiles of QTc PRS -

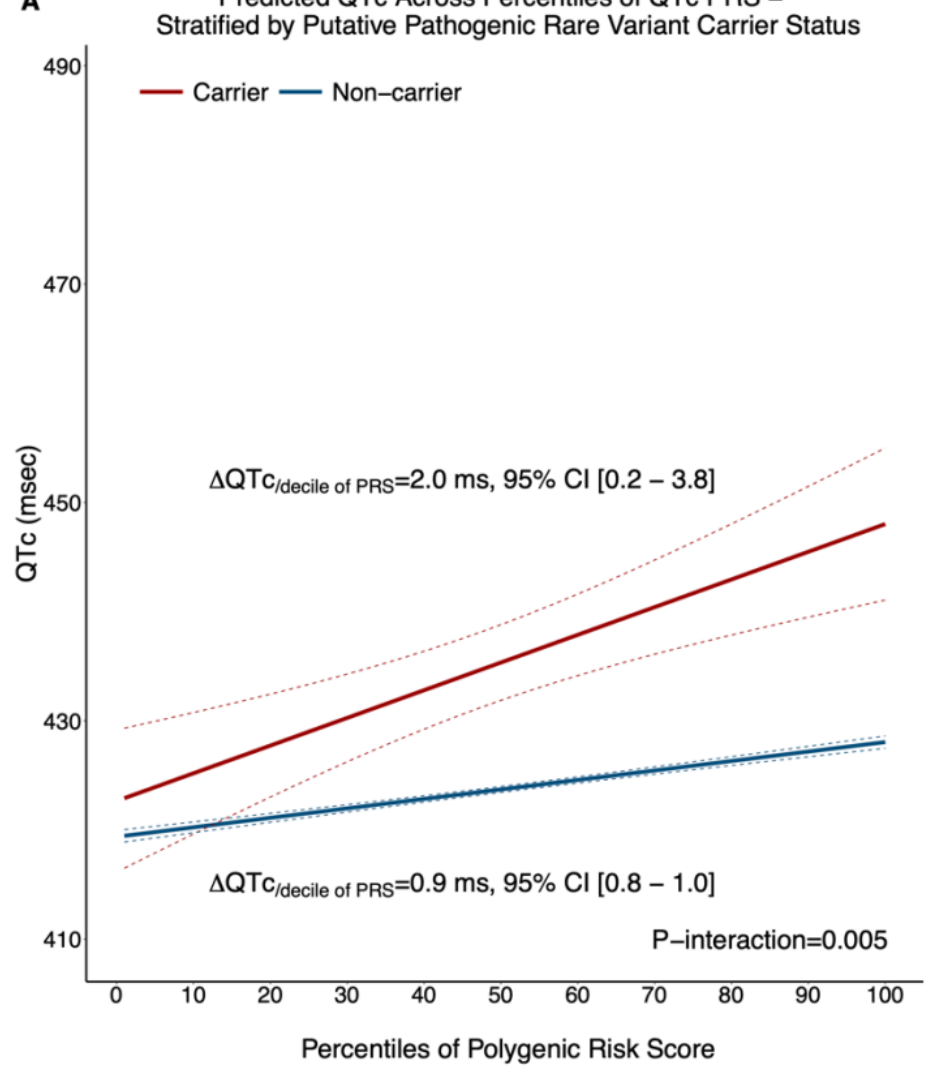

B Predicted QTc Across Percentiles of QTc PRS - Stratified by Putative Pathogenic Rare Variant Carrier Status (KCNQ1, KCNH2, SNC5A)

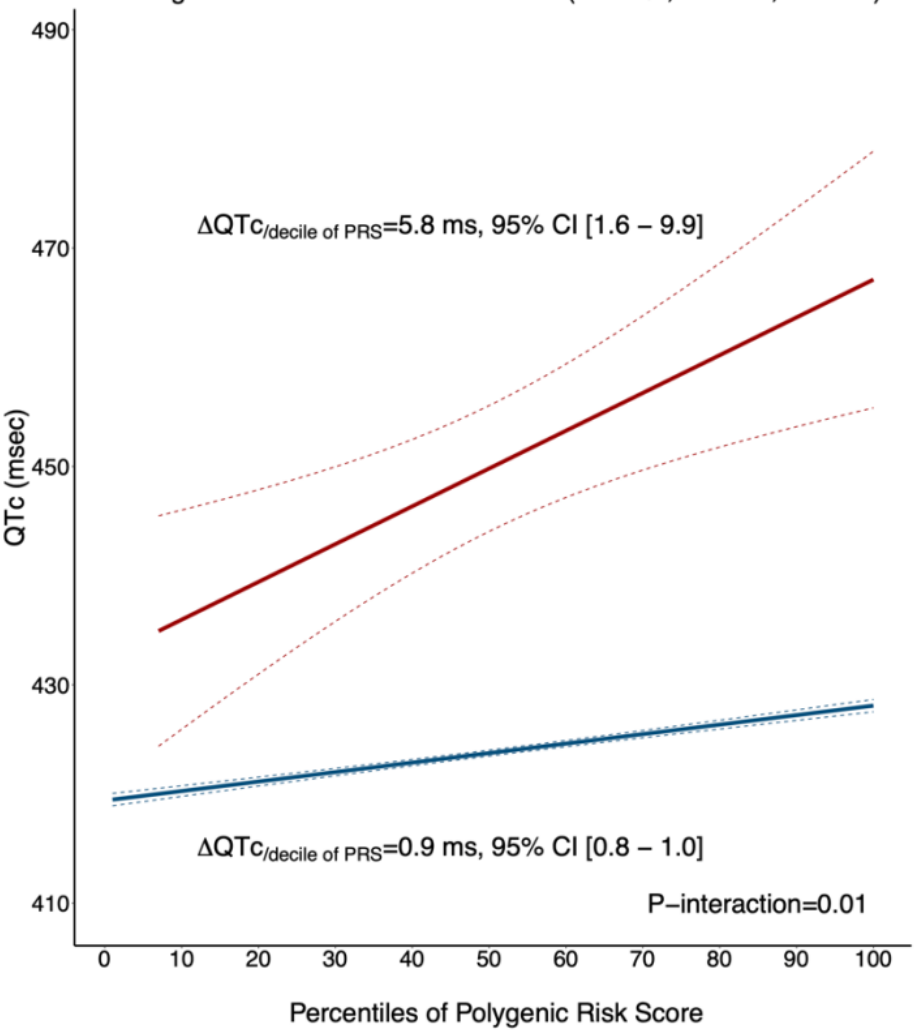

Figure 4. Variation in the Predicted QTc Across Percentiles of the Polygenic Risk Score stratified by Putative Pathogenic Rare Variant Carrier Status in all long QT Syndrome genes (A) and in $K C N Q 1, K C N H 2$ and SCN5A (B). 


\section{Association of Putative Pathogenic Rare Variant in LQTS Genes Carrier Status with QTc Interval Across Tertiles of QTc PRS}

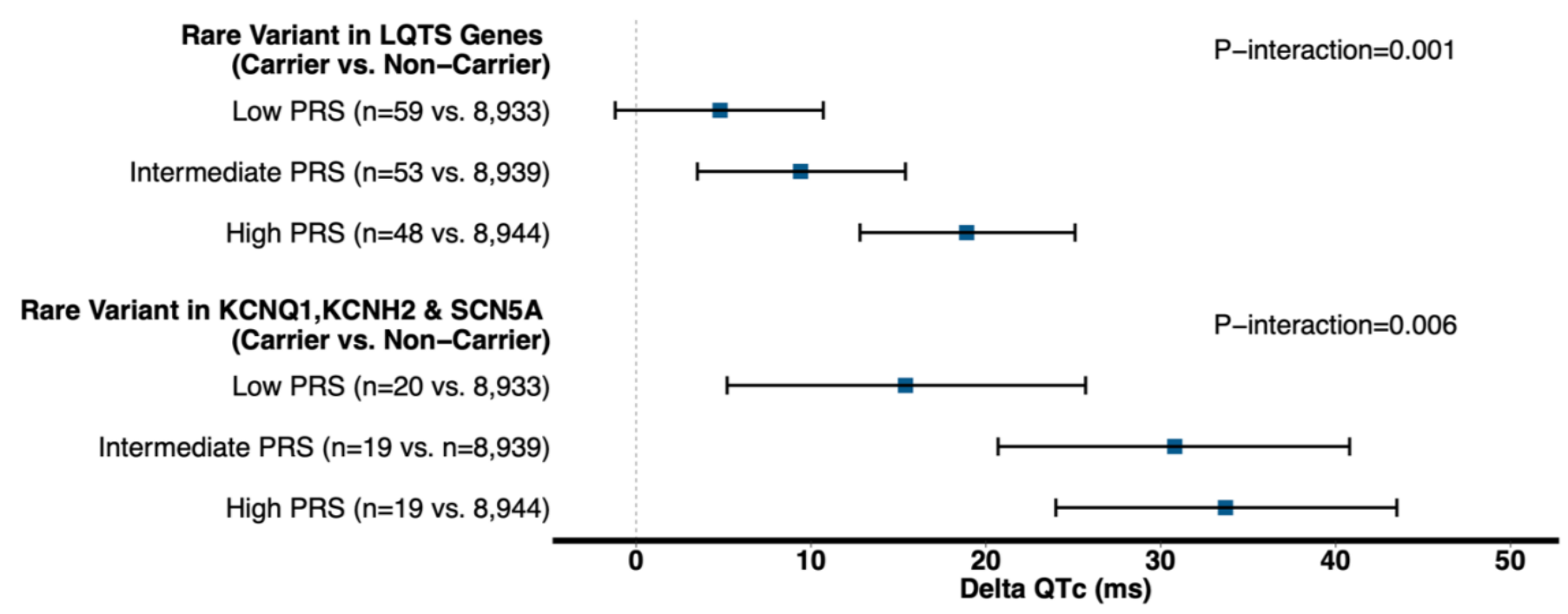

Figure 5. Multivariable Association of Putative Pathogenic Rare Variant Carrier Status with QTc Interval Duration Across Tertiles of QTc Polygenic Risk Score. Low, intermediate and high PRS strata reflect first, second and third tertiles of the PRS in the study sample, respectively. 


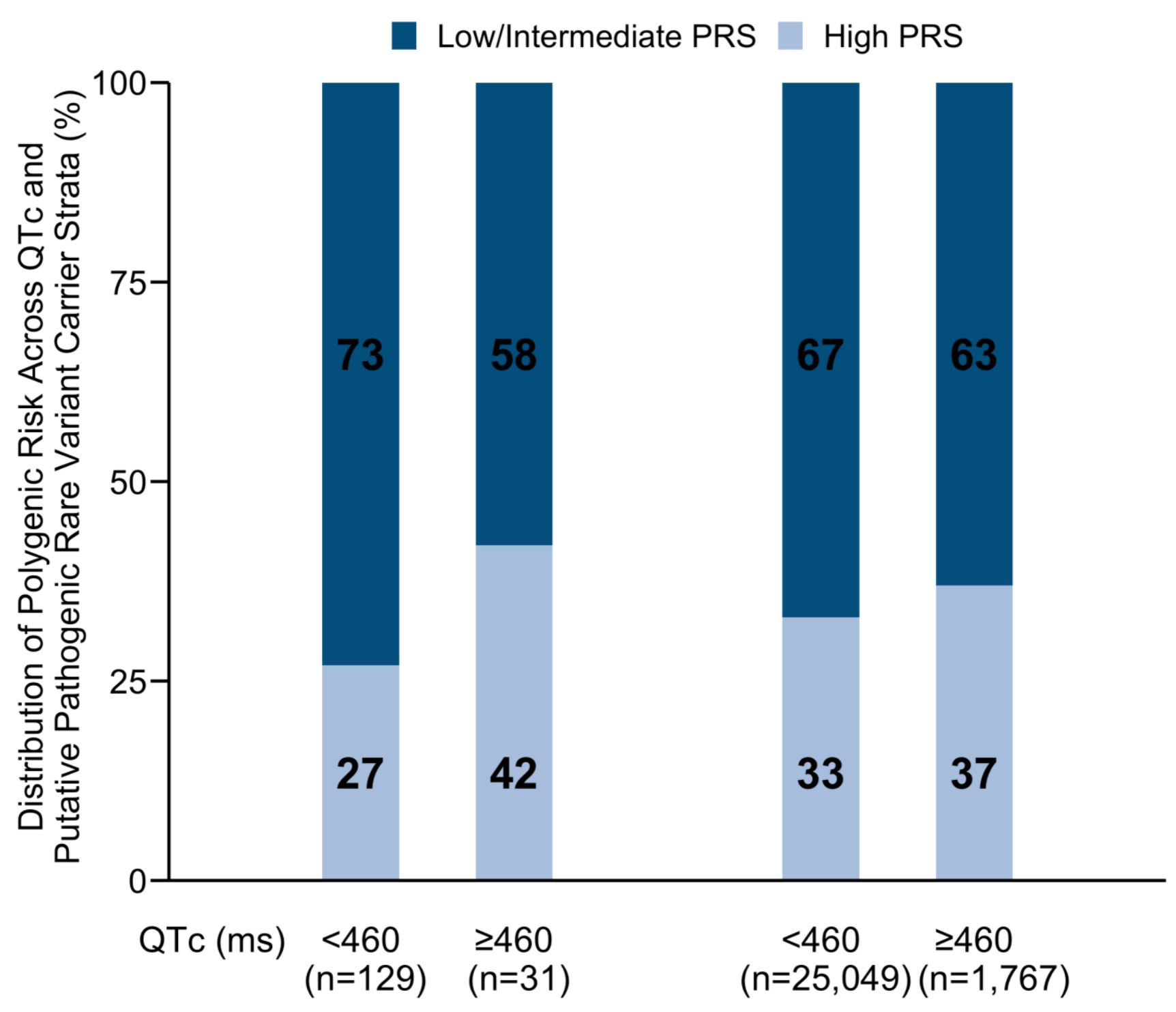

\section{Carriers}

Non-Carriers

Figure 6. Distribution of Low/Intermediate and High Polygenic Risk in Individuals with Normal ( $<460 \mathrm{~ms})$ and Prolonged QTc Intervals $(\geq 460 \mathrm{~ms})$ among Carriers and non-Carriers of Putative Pathogenic Rare Variants in Long QT Syndrome genes. Low, intermediate and high PRS strata reflect first, second and third tertiles of the PRS in the study sample, respectively. 